\section{Case Reports in Dermatology}

Case Rep Dermatol 2017;9:79-85

DOI: $10.1159 / 000477960$

Publisned online: July 13, 2017
(C) 2017 The Author(s)

Published by S. Karger AG, Basel www.karger.com/cde

This article is licensed under the Creative Commons Attribution-NonCommercial 4.0 International License (CC BY-NC) (http://www.karger.com/Services/OpenAccessLicense). Usage and distribution for commercial purposes requires written permission.

\title{
Extrafacial Granuloma Faciale: A Case Report and Brief Review
}

\author{
Jacqueline Deen ${ }^{a} \quad$ Thomas P. Moloney ${ }^{b} \quad$ Jim Muir $^{a}$ \\ ${ }^{a}$ Department of Dermatology, Mater Misericordiae Hospital, Brisbane, QLD, Australia; \\ ${ }^{\mathrm{b}}$ Princess Alexandra Hospital, Brisbane, QLD, Australia
}

\section{Keywords}

Granuloma faciale $\cdot$ Extrafacial granuloma faciale $\cdot$ Lymphoma

\begin{abstract}
Granuloma faciale (GF) is a rare, inflammatory, cutaneous disorder of unknown aetiology. It presents clinically as one or several well-circumscribed violaceous papules, plaques, and nodules almost exclusively confined to the facial region. Rarely, extrafacial lesions can occur, most often on sun-exposed sites. We report a case of extrafacial GF in a 63-year-old male with indolent lymphoma, who presented with plaques involving the right preauricular region and left posterior axilla. The clinical and histopathological findings were consistent with GF. Our case highlights the importance of performing skin biopsies in patients with persistent erythematous plaques and nodules, particularly to exclude important malignant and granulomatous differential diagnoses.

(C) 2017 The Author(s)

Published by S. Karger AG, Basel
\end{abstract}




\section{Introduction}

Granuloma faciale (GF) is a rare, benign, chronic inflammatory skin condition of unknown aetiology. It has a predilection for middle-aged Caucasian males, but still occurs in females and other age groups. Actinic damage has been suggested to play a role in the development of GF [1].

Clinically it manifests as one or several erythematous-to-livid plaques or nodules, with associated superficial telangiectasias and follicular accentuation [2]. It typically occurs on the face; however, disseminated or extrafacial lesions have been reported. GF is usually asymptomatic or associated with mild pruritus, with patients typically seeking treatment due to its chronic course and cosmetic disfigurement. A diagnosis is made by typical clinical features and confirmed by histopathology $[2,3]$.

We report a rare case of GF with extrafacial involvement which was successfully treated with intralesional corticosteroids, and we briefly review previously reported cases of extrafacial GF.

\section{Case Report}

A 63-year-old male with a past medical history of lymphoma presented with a 2-year history of a reddish/brown plaque in the right preauricular region with associated swelling and tenderness. The plaque had fluctuated in size over the preceding months, and there was associated right-sided facial paraesthesia. There was no associated pruritus, history of local skin trauma, or discharge from the site. On further questioning, the patient had a 2-month history of a similar-appearing plaque on the left posterior axilla. The patient was otherwise systemically well, with no fevers, night sweats, fatigue, weight loss, or symptoms of infection.

The patient's past medical history included indolent lymphoma with monoclonal gammopathy, Sjögren syndrome, and gastro-oesophageal reflux disease. His only regular medication was esomeprazole and he had no known drug allergies. He was an ex-smoker and rarely consumed alcohol.

A physical examination revealed a well-demarcated violaceous plaque in the right preauricular region with central ulceration. Follicular plugging was not prominent. The mass was firm, rubbery, and mobile on palpation (Fig. 1). There was a flattened, erythematous, atrophic plaque with induration in the left posterior axilla (Fig. 2). There was no palpable lymphadenopathy or hepatosplenomegaly, and the general examination was otherwise unremarkable. A provisional diagnosis of GF was made; however, given the patient's history of lymphoma, a further investigation to exclude cutaneous malignancy was warranted.

A full blood count, his urea/electrolyte values, and renal and liver function were all normal. An ultrasound of the right preauricular region and a CT scan of the head and neck were also unremarkable. Two cutaneous punch biopsies were taken from the plaques in the right preauricular region and the left posterior axilla. The histology of the two specimens showed similar findings. The epidermis was unremarkable, and there was a thin grenz zone of unremarkable dermis superficially. Deep to this, throughout the full thickness of the dermis, there was a moderately dense, inflammatory infiltrate including neutrophils, lymphocytes, plasma cells, and eosinophils. These were arranged in tight perivascular cuffs. Some of 
the vessels showed swelling of endothelial cells with infiltration of vessel walls by neutrophils. There was no true fibrinoid necrosis or leukocytoclasis. Small aggregates of foamy histiocytes were noted within the superficial dermis. The distribution of inflammatory changes was in keeping with GF. The patient opted for conservative management of his lesions with intralesional corticosteroids, and these remained stable thereafter.

\section{Discussion}

Extrafacial involvement in GF was first reported by Lever et al. [4] in 1948 following the discovery of upper back lesions in a patient. GF commonly occurs as solitary lesions on sunexposed areas of the face, with preferential sites including the nose, periauricular area, cheeks, forehead, eyelids, and ears. Extrafacial involvement (with or without associated facial involvement) may also occur, often on the trunk and extremities [3].

The term "granuloma" is a misnomer, as granulomas are not a histologic feature of this condition. The characteristic features on skin biopsy include a diffuse, polymorphous dermal infiltrate consisting of neutrophils, lymphocytes, and eosinophils in conjunction with small vessel vasculitis. Frequently there is a thin, uninvolved area of papillary dermis that separates the epidermis from the inflammatory infiltrate, termed "grenz zone" [2-5]. Histology is important to distinguish GF from other dermatoses. Differential diagnoses include cutaneous sarcoidosis, cutaneous lymphoma, pseudolymphoma, cutaneous lupus erythematosus, mycosis fungoides, and fixed drug eruption [6].

To our knowledge there have been 32 previously reported cases of extrafacial GF (Table 1) [1-25]. In these cases the average age of the patients was 51 years, with $68.5 \%$ being male. In terms of the sites of extrafacial GF, these included the trunk in 19 cases (59\%), the upper extremities in 14 cases (44\%), the scalp in 8 cases $(25 \%)$, the lower extremities and neck each in 2 cases $(6 \%)$, and the vulva in 1 case. Interestingly, $31 \%$ of the cases had extrafacial lesions occurring alone, without associated facial lesions.

As shown by our review of previous cases of extrafacial GF, sites of predilection include the trunk and upper extremities. Therefore, although rare, extrafacial GF should be included in the differential diagnosis of chronic violaceous plaques/nodules in these areas, particularly in middle-aged males.

Given the broad clinical differential diagnosis, our case highlights the importance of performing skin biopsies on any chronic erythematous plaques or nodules. This was particularly relevant in our patient given his atypical presentation with extrafacial lesions involving the posterior axilla and his history of lymphoma and Sjögren syndrome. This necessitated exclusion of other cutaneous disorders, particularly malignancy and autoimmune conditions. Furthermore, the associated medical comorbidities of patients with extrafacial GF are typically variable - but all with potential dermatological manifestations needing consideration.

\section{Statement of Ethics}

The authors have no ethical conflicts to disclose. 


\section{Disclosure Statement}

The authors have no competing interests/conflicts of interest and no funding sources to disclose.

\section{References}

1 Castellano-Howard L, Fairbee SI, Hogan DJ, Fenske NA, Messina JL: Extrafacial granuloma faciale: report of a case and response to treatment. Cutis 2001;67:413-415.

2 Ortonne N, Wechsler J, Bagot M, Grosshans E, Cribier B: Granuloma faciale: a clinicopathologic study of 66 patients. J Am Acad Dermatol 2005;53:1002-1009.

-3 Pedace FJ, Perry HO: Granuloma faciale. A clinical and histopathologic review. Arch Dermatol 1966;94:387-395.

4 Lever WF, Lane CG, Downing JG, Spangler AS: Eosinophilic granuloma of the skin; report of three cases. Arch Dermat Syphilol 1948;58:430-438.

$>5$

$>6$

$>7$ Pratap DV, Putta S, Manmohan G, Aruna S, Geethika M: Granuloma faciale with extra-facial involvement. Indian J Dermatol Venereol Leprol 2010;76:424-426.

Okun MR, Bauman L, Minor D: Granuloma faciale with lesions on the face and hand. Arch Dermatol 1965;92:78-80.

Frost FA, Heenan PJ: Facial granuloma. Australas J Dermatol 1984;25:121-124.

Sears JK, Gitter DG, Stone MS: Extrafacial granuloma faciale. Arch Dermatol 1991;127:742-743.

Konohana A: Extrafacial granuloma faciale. J Dermatol 1994;21:680-682.

Kavanagh GM, McLaren KM, Hunter JA: Extensive extrafacial granuloma faciale of the scalp. Br J Dermatol 1996;134:595-596.

$>12$

$>13$ extrafacial location. Br J Dermatol 1997;136:978-979.

$>14$

15

$>16$

$>17$

$>18$

19

Castaño E, Segurado A, Iglesias L, López-Ríos F, Rodríguez-Peralto JJ: Granuloma faciale entirely in an 1999;198:79-82.

Inanir I, Alvur Y: Granuloma faciale with extrafacial lesions. Br J Dermatol 2001;145:360-362.

Zargari O: Disseminated granuloma faciale. Int J Dermatol 2004;43:210-212.

Marcoval J, Moreno A, Peyrí J: Granuloma faciale: a clinicopathological study of 11 cases. J Am Acad Dermatol 2004;51:269-273.

Verma R, Das AL, Vaishampayan SS, Vaidya S: Keloidal granuloma faciale with extrafacial lesions. Indian J Dermatol Venereol Leprol 2005;71:345-347.

Nigar E, Dhillon R, Carr E, Matin RN: Eosinophilic angiocentric fibrosis and extrafacial granuloma faciale. Histopathology 2007;51:729-731.

Rossiello L, Palla M, Aiello FS, Baroni A, Satriano RA: Granuloma faciale with extrafacial lesions. Skinmed 2007;6:150-151.

Sewell L, Elston D: Extrafacial granuloma faciale successfully treated with 595-nm pulse dye laser. J Am Acad Dermatol 2008;58(suppl 2):AB141.

Nasiri S, Rahimi H, Farnaghi A, Asadi-Kani Z: Granuloma faciale with disseminated extra facial lesions. Dermatol Online J 2010;16:5.

Leite I, Moreira A, Guedes R, Furtado A, Ferreira EO, Baptista A: Granuloma faciale of the scalp. Dermatol Online J 2011;17:6.

Gupta L, Naik H, Kumar NM, Kar HK: Granuloma faciale with extrafacial involvement and response to tacrolimus. J Cutan Aesthet Surg 2012;5:150-152.

Singh SK, Rai T, Sharma T: A rare case of keloidal granuloma faciale with extra-facial lesions. Indian Dermatol Online J 2013;4:27-29.

Surana TV, Arghyaprasun G, Saugato B, Falguni N, Gobinda C, Chinmay H: Granuloma faciale: exclusively extrafacial. Indian J Dermatol 2013;58:245. 


\section{Case Reports in Dermatology}

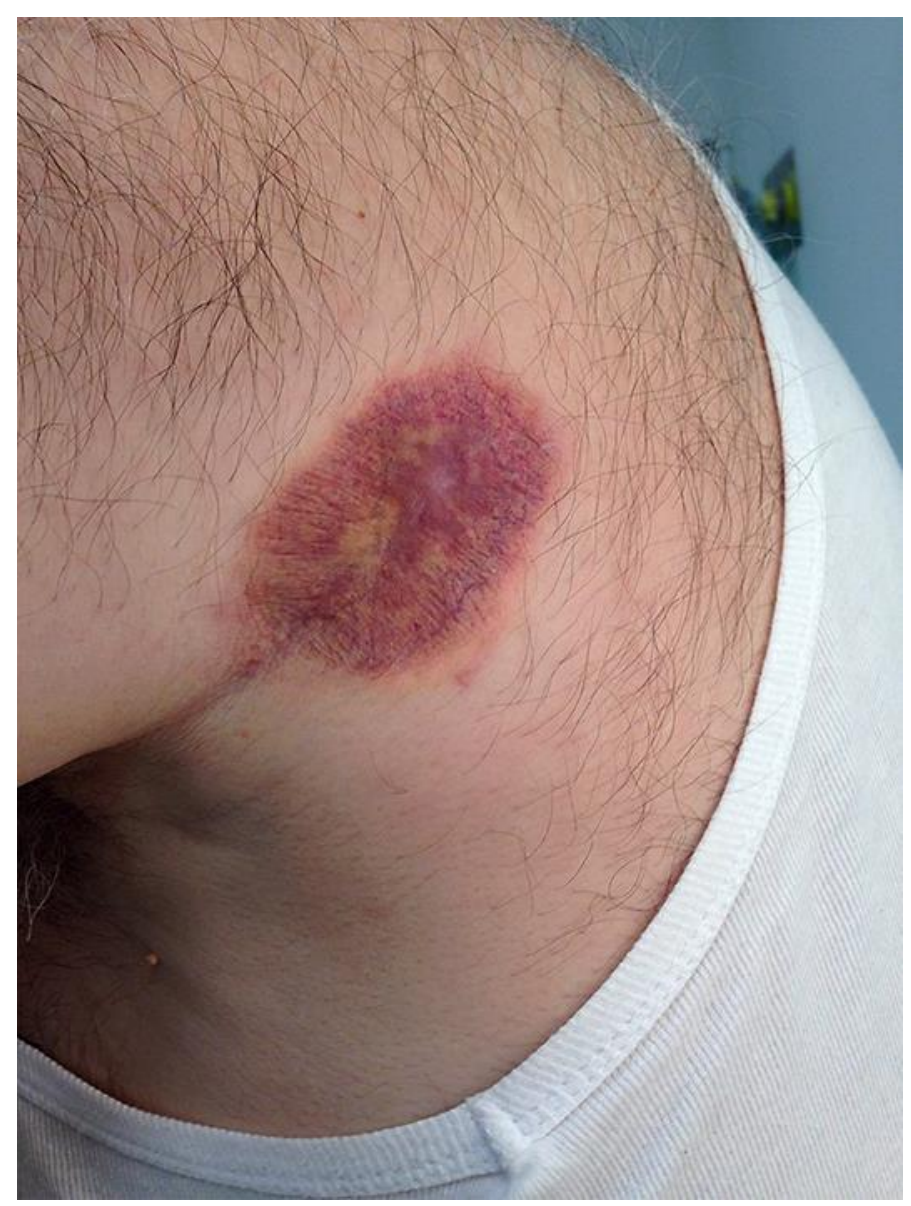

Fig. 1. Extrafacial granuloma faciale lesion at the left posterior axilla. 


\section{Case Reports in Dermatology}

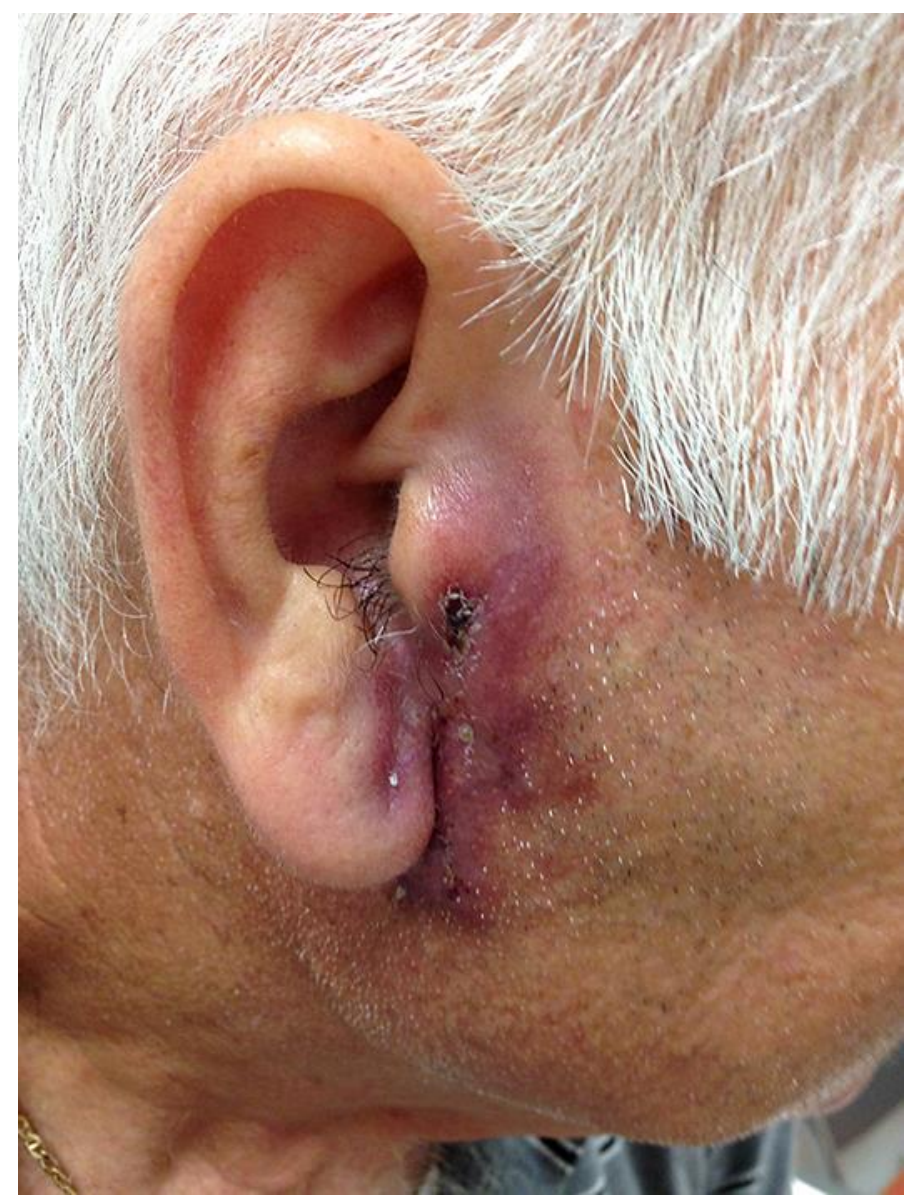

Fig. 2. Well-demarcated violaceous plaque in the right preauricular region with central ulceration. 
Table 1. Previously reported cases of extrafacial granuloma faciale

\begin{tabular}{|c|c|c|c|c|c|c|}
\hline $\begin{array}{l}\text { Case } \\
\text { No. }\end{array}$ & Author & $\begin{array}{l}\text { Age, } \\
\text { years }\end{array}$ & Gender & $\begin{array}{l}\text { Facial } \\
\text { lesions }\end{array}$ & Extrafacial localization & Medical comorbidities \\
\hline 1 & Lever et al. (1948) [4] & 53 & M & + & Trunk & Not reported \\
\hline 2 & Okun et al. (1965) [7] & 54 & $\mathrm{~F}$ & + & Upper extremities & Good general health \\
\hline$\overline{3}$ & Pedace and Perry (1966) [3] & 45 & M & + & Upper extremities & $\begin{array}{l}\text { Mycosis fungoides, sarcoidosis, } \\
\text { neurodermatitis }\end{array}$ \\
\hline 4 & & 47 & $\mathrm{~F}$ & + & Neck, trunk, upper extremities & $\begin{array}{l}\text { Discoid lupus erythematosus, mycosis } \\
\text { fungoides }\end{array}$ \\
\hline 5 & Rusin et al. (1976) [5] & 44 & $\mathrm{M}$ & + & Upper extremity, trunk & Not reported \\
\hline 6 & & 50 & $\mathrm{~F}$ & + & Trunk & Not reported \\
\hline 7 & Frost and Heenan (1984) [8] & 64 & $\mathrm{M}$ & + & Scalp, upper extremities & Solar keratosis and BCCs \\
\hline 8 & Sears et al. (1991) [9] & 57 & $\mathrm{M}$ & + & Neck, lower extremities & $\begin{array}{l}\text { Chronic urticaria, glaucoma, allergic } \\
\text { rhinitis, idiopathic renal calculi }\end{array}$ \\
\hline$\overline{9}$ & Konohana (1994) [10] & 59 & $\mathrm{M}$ & + & Trunk & Depression, chronic hepatitis \\
\hline 10 & Kavanagh et al. (1996) [11] & 62 & $\mathrm{M}$ & - & Scalp & Alzheimer disease \\
\hline$\overline{11}$ & Castaño et al. (1997) [12] & 51 & $\mathrm{~F}$ & - & Trunk & Not reported \\
\hline 12 & Roustan et al. (1999) [13] & 38 & $\mathrm{M}$ & + & Trunk, upper extremity & Unremarkable \\
\hline 13 & Inanir and Alvur (2001) [14] & 47 & $\mathrm{~F}$ & + & Neck, upper extremity & Pulmonary tuberculosis (latent) \\
\hline$\overline{14}$ & Castellano-Howard et al. (2001) [1] & 57 & $\mathrm{M}$ & + & Trunk & Not reported \\
\hline 15 & Zargari (2004) [15] & 40 & $\mathrm{M}$ & + & Trunk, upper extremities & Good general health \\
\hline$\overline{16}$ & Marcoval et al. (2004) [16] & 68 & $\mathrm{M}$ & + & Scalp, trunk & Not reported \\
\hline 17 & & 58 & $\mathrm{~F}$ & + & Scalp, trunk & Not reported \\
\hline 18 & Verma et al. (2005) [17] & 52 & $\mathrm{~F}$ & + & Upper extremity, trunk & Not reported \\
\hline$\overline{19}$ & Ortonne et al. (2005) [2] & 44 & $\mathrm{~F}$ & - & Vulva & $\begin{array}{l}\text { No Hx of cutaneous and systemic } \\
\text { disease }\end{array}$ \\
\hline 20 & & 61 & M & - & Scalp & $\begin{array}{l}\text { No Hx of cutaneous and systemic } \\
\text { disease }\end{array}$ \\
\hline 21 & & 55 & M & - & Trunk & $\begin{array}{l}\text { No Hx of cutaneous and systemic } \\
\text { disease }\end{array}$ \\
\hline 22 & & 52 & M & - & Trunk & $\begin{array}{l}\text { No Hx of cutaneous and systemic } \\
\text { disease }\end{array}$ \\
\hline 23 & & 43 & M & + & Upper extremity, scalp & $\begin{array}{l}\text { No Hx of cutaneous and systemic } \\
\text { disease }\end{array}$ \\
\hline 24 & Nigar et al. (2007) [18] & 67 & $\mathrm{M}$ & - & Trunk & Not reported \\
\hline 25 & Rossiello et al. (2007) [19] & 35 & $\mathrm{M}$ & + & Trunk & Not reported \\
\hline 26 & Sewell and Elston (2008) [20] & 54 & $\mathrm{M}$ & - & Scalp & Not reported \\
\hline 27 & Nasiri et al. (2010) [21] & 39 & $\mathrm{M}$ & + & Upper extremities, trunk & Unremarkable \\
\hline 28 & Pratap et al. (2010) [6] & 30 & $\mathrm{~F}$ & + & Trunk & Not reported \\
\hline 29 & Leite et al. (2011) [22] & 78 & $\mathrm{M}$ & - & Scalp & Not reported \\
\hline 30 & Gupta et al. (2012) [23] & 35 & $\mathrm{~F}$ & + & Upper extremities, trunk & Unremarkable \\
\hline$\overline{31}$ & Singh et al. (2013) [24] & 33 & $\mathrm{M}$ & + & Upper extremity & Not reported \\
\hline$\overline{32}$ & Surana et al. (2013) [25] & 60 & $\mathrm{M}$ & - & $\begin{array}{l}\text { Upper extremities (fingers), lower } \\
\text { extremities (toes) }\end{array}$ & Not reported \\
\hline
\end{tabular}

Trunk = chest, abdomen, and back; upper extremity = shoulder, arm, forearm, wrist, and hand; lower extremity = hip, thigh, leg, ankle, and foot. BCCs, basal cell carcinomas; Hx, history. 